\title{
REFLEKSI NILAI BUDAYA DALAM UNGKAPAN TRADISIONAL MASYARAKAT LUBUKLINGGAU SUMATERA SELATAN
}

\section{CULTURAL VALUES REFLECTIONS IN TRADITIONS EXPRESSIONS WITHIN LUBUKLINGGAU COMMUNITY IN SOUTH SUMATERA PROVINCE}

\author{
Hasanadi \\ Balai Pelestarian Nilai Budaya Sumatera Barat \\ Jl. Raya Belimbing No.16 A, Kuranji Padang \\ E-mail: hassanasyahda@gmail.com \\ DOI: $10.36424 / j p s b . v 5 i 1.32$ \\ Naskah Direvisi: 4 Mei 2019 Naskah Disetujui: 1 Juni 2019
}

\begin{abstract}
Abstrak
Penelitian ini menelaah nilai budaya masyarakat Lubuklinggau Sumatera Selatan melalui berbagai ungkapan tradisional. Ungkapan tradisional dimaksud adalah : (1) Ungkapan payu ponga nilek ngelup. Jengan melawan wang tue nilek meresak; (2) Ungkapan awak tue betunak daak hiyang melam kire nak ngelong; (3) Ungkapan lah ngidar lah baputar lom dəpat jelan hatuju; (4) Ungkapan makan ati nenggung sedingan rube abis resan urung; (5) Ungkapan lambat bekat gacang dəpat. Dengan menggunakan pendekatan sosiologi sastra serta diperkuat dengan analisis hermeneutik peneliti menyimpulkan bahwa bahwa kelima ungkapan dimaksud merefleksikan nilai budaya masyarakat Lubuklinggau, terutama terkait dengan beberapa hal, yaitu : (1) Perlunya komitmen untuk senentiasa berbakti dan patuh kepada orang tua; (2) Pentingnya isteri sebagai pasangan hidup serta kesungguhan menjaga keutuhan keluarga; (3) Perlunya pengetahuan dalam memahami dinamika dialog yang berkembang di tengah masyarakat; (4) Perlunya kompromi dalam menjaga jalinan silaturahim antar warga masyarakat; dan (5) Pentingnya kecermatan sekaligus kecepatan dalam setiap bidang usaha yang ditekuni.

Kata kunci : refleksi nilai budaya, ungkapan tradisional, Lubuklinggau
\end{abstract}

\begin{abstract}
This research investigates cultural values reflection existing within Lubuklinggau community in South Sumatera Province through several of traditional expressions. They are: 1) Expression of payu ponga nilek ngelup. Jengan melawan wang tue nilek meresak; (2) Expression of awak tue betunak daak hiyang melam kire nak ngelong; (3) Expression of lah ngidar lah baputar lom dopat jelan hatuju; (4) Expression of makan ati nenggung sedingan rube abis resan urung; (5) Expression of lambat bekat gacang dəpat. By using The approach of the sociology of literature and Supported by hermeneutic analysis, it was concluded the five expressions reflect the cultural values of Lubuklinggau community, especially related to several life aspect, namely: (1) The need for a perennial commitment to be consistent and
\end{abstract}


obedient to parents; (2) The importance of wife presence as a life partner and the significance of maintaining the integrity of family; (3) The need for knowledge in understanding the dynamics of dialogue that arises within community; (4) The need to compromise in maintaining friendship and healthy relationship amidst citizens; and (5) The importance of accurateness as well as swiftness in every field of engaged business.

Keywords: cultural values reflections, traditional expressions, Lubuklinggau

\section{PENDAHULUAN}

Tulisan ini membicarakan ungkapan tradisional masyarakat Lubuklinggau Provinsi Smatera Selatan, yaitu salah satu warisan kesusastraan yang mencakup ekspresi kebudayaan masyarakat Lubuklinggau serta disebarluaskan secara turun temurun dari mulut ke mulut. Dalam konteksnya sebagai warisan kesusastraan lisan, ungkapan tradisional Lubuklinggau memiliki ciri sebagaimana sastra lisan pada umumnya. Sebagaimana dijelaskan Hutomo (1991: 43) sastra lisan memiliki beberapa ciri, yaitu : (1) bersifat anonim; (2) materi ungkapan bersifat kolektif, tradisional, dan berfungsi khas bagi masyarakatnya; (3) mempunyai bentuk tertentu dan varian; dan (4) berkaitan dengan pengetahuan dan kepercayaan tradisional. Namun demikian, dijelaskan juga oleh Atmazaki (2005: 137-139), meskipun sastra lisan dianggap anonim, besar kemungkinan bahwa menghilangan penciptanya disebabkan oleh karena sastra lisan merupakan pancaran kreasi masyarakat lama yang dianggap sebagai milik bersama.

Kajian terhadap ungkapan tradisional Lubuklinggau penting untuk dilakukan. Pertama, kajian ini menjadi penting terkait luarannya berupa dokumentasi teks ungkapan tradisional. Sebagaimana disebutkan Sedyawati (2006: 164), suatu sumber daya budaya (SDB) mempunyai kaidah-kaidah penanganannya, seperti melakukan pendokumentasian dan pengarsipan yang sebaik-baiknya untuk kepentingan ilmiah, dan pengemasan dalam berbagai bentuk untuk kepentingan industri budaya serta pemenuhan kebutuhan penikmat juga 'pemihakan' oleh khalayak ramai. Sumber daya budaya (SDB) memiliki dua jenis, yaitu, sumber daya budaya yang tangible (benda konkrit yang dapat disentuh, dilihat dan dirasakan) dan sumber daya budaya yang intangible yakni benda yang tak berwujud, yang mana 
aspek-aspek benda tak berwujud itu meliputi, konsep mengenai benda itu, perlambangan yang diwujudkan melalui benda itu, kebermaknaannya, dll.

Kedua, kajian ungkapan tradisional Lubuklinggau menjadi penting terkait perlunya pewarisan nilai budaya yang terdapat pada ungkapan kepada masyarakat, khususnya kepada generasi muda. Masyarakat Lubuklinggau perlu memahami bentuk-bentuk pengetahuan tradisional, kebijaksanaan-kebijaksanaan, serta sikap budaya sebagaimana terefleksi pada berbagai ungkapan tradisional dimaksud. Sebagaimana dijelaskan Koenjraningrat (2002: 26), sebagai bagian dari adat istiadat dan wujud idiil dari kebudayaan, nilai budaya seolah-olah berada di luar dan di atas diri para individu yang menjadi warga masyarakat yang bersangkutan. Para individu itu sejak kecil telah diresapi dengan nilai-nilai budaya yang hidup dalam masyarakatnya, sehingga konsepsi-konsepsi itu sejak lama telah berakar dalam jiwa mereka. Itulah sebabnya nilai-nilai budaya tadi sukar diganti dengan nilai-nilai budaya lain dalam waktu yang singkat.

Usaha penguatan karakter masyarakat dan khususnya generasi muda melalui pewarisan nilai budaya seperti halnya terefleksi pada berbagai ungkapan tradisional Lubuklinggau berhadapan dengan berbagai kendala dan tentangan. Menurut Rusmana Dewi, akademisi serta pemerhati sastra dan budaya masyarakat Lubuklinggau (wawancara tanggal 25 September 2018), tantangan terbesar yang dihadapi dalam usaha pewarisan nilai budaya tersebut berasal dari kemajuan ilmu pengetahuan serta berkembangnya teknologi informasi. Semakin dekatnya keseharian warga masyarakat khususnya generasi muda dengan teknologi informasi seperti handphone telah berdampak pada semakin jaraknya mereka dengan khasanah nilai budaya lokal sebagaimana terefleksi pada ungkapan tradisional. Di lain pihak, sebagian anggota lembaga adat, baik di tingkat Kota Lubuklinggau maupun di tingkat kecamatan dan desa/kelurahan memiliki keterbatasan pengetahuan tentang nilai budaya yang terdapat pada ungkapan tradisional, di samping adanya persoalan waktu dan kesempatan untuk melakukan proses pembelajaran serta pewarisan kepada generasi muda. Pada konteks pola hubungan sosial budaya yang lebih sempit, misalnya pola hubungan antara orang 
tua dan anak, tuntutan zaman telah menggiring untuk melebarnya jarak yang memungkinkan berlangsungnya transmisi nilai pemahaman serta pengetahuan terhadap berbagai ungkapan tradisional.

Secara normatif kepedulian para tokoh masyarakat Kota Lubuklinggau yang tergabung dalam struktur lembaga adat mulai dari tingkat desa/kelurahan, kecamatan dan kota, terus dituntut agar mampu mendorong munculnya gagasan kreatif yang bersifat kelembagaan sehingga mewadahi berlangsungnya proses transpormasi nilai budaya kepada masyarakat. Menurut Suwandi Syam, peneliti aksara Kaganga sekaligus pemerhati sejarah dan budaya masyarakat Lubuklinggau (wawancara tanggal 26 September 2018), sikap kelembagaan para anggota Lembaga Adat Kota Lubuklinggau yang terus melakukan percepatan pengetahuan tentang nilai budaya, misalnya melalui pelahiran kegiatan dialog budaya, diharapkan mampu menumbuh kembangkan semangat serta kepedulian masyarakat dalam mempelajari ulang kebudayaan. Konsekuensi yang diharapkan adalah, nilai budaya ungkapan tradisional terwariskan melalui kegiatan dialog tersebut, sehingga upaya pembentukan karakter masyarakat khususnya generasi muda berbasis nilai budaya lokal terus berlanjut serta menguat.

Berkaitan dengan itu, tulisan yang diramu ulang dari laporan kajian tentang ungkapan tradisional masyarakat Lubuklinggau ini diyakini mampu memperkaya ide, gagasan, dan khasanah pengetahuan anggota Lembaga Adat Kota Lubuklinggau serta warga masyarakat pada umumnya dalam upaya memahami nilai budaya yang terefleksi pada berbagai ungkapan tradisional Lubuklinggau yang berhasil didokumentasi. Pertanyaan penting yang ingin dijawab melalui tulisan ini adalah, bagaimana nilai budaya masyarakat Lubuklinggau sebagaimana terefleksi melalui teks ungkapan tradisional ?. Hemat penulis, pengetahuan serta pemahaman terhadap refleksi nilai budaya tersebut menjadi relevan dalam menopang sinergi kelembagaan dalam setiap kegiatan sosial budaya yang berlangsung serta dimaksudkan sebagai media pembelajaran serta pewarisan nilai budaya kepada masyarakat khususnya generasi muda Lubuklinggau. 


\section{METODE PENELITIAN}

Pendekatan sosiologi sastra pada dasarnya memunculkan dua pengertian secara bersamaan, yaitu pengertian tentang sosiologi dan pemahaman tentang sastra secara bersamaan. Sosiologi adalah ilmu yang mempelajari struktur sosial, prosesproses sosial, termasuk di dalamnya perubahan sosial. Sedangkan sastra adalah salah satu lembaga sosial yang menggunakan bahasa sebagai mediumnya. Bahasa merupakan ciptaan sosial sementara sastra menampilkan gambaran kehidupan dan kehidupan itu sendiri adalah kenyataan sosial (Damono, 1984: 2). Artinya, sosiologi dan sastra mempunyai objek yang berurusan dengan manusia dan kehidupannya. Setiap karya sastra memberikan gambaran tentang kehidupan suatu masyarakat, setidak-tidaknya gambaran tentang pribadi seseorang. Sebagaimana dikatakan Damono (1984: 4), karya sastra tidak dapat dipahami secara selengkap-lengkapnya apabila dipisahkan dari lingkungan atau kebudayaan-peradaban yang melahirkannya. Ia harus dipelajari dalam konteks seluas-luasnya, tidak hanya dirinya sendiri. Setiap karya sastra adalah hasil dari pengaruh timbal balik yang rumit antara pengarang dengan masyarakat, karena karya sastra itu adalah objek kultural yang rumit, serta ia bukanlah gejala tersendiri yang terpisah.

Sastra bukanlah suatu bentuk komunikasi yang bersifat praktis, yang isi dan maksudnya secara langsung dapat diketahui, tertangkap dan terpahami layaknya seseorang membaca atau mendengar karya-karya yang bukan sastra (Luxemburg dkk, 1984: 9). Selanjutnya, sosiologi sastra pada hakekatnya merupakan suatu pendekatan sastra dengan mempertimbangkan segi-segi kemasyarakatan (Damono, 1984: 4). Setiap karya sastra berasal dan berakar dari suatu lingkungan sosial, dinikmati oleh masyarakat, baik itu sebagai media hiburan atau sebagai penyampaian pesan-pesan yang berisi nilai-nilai pengajaran dalam kehidupan. Berkaitan dengan itu, analisis terhadap ungkapan tradisional masyarakat Lubuklinggau menggunakan pendekatan sosiologi sastra, dengan tujuan melihat hubungan antara ungkapan tersebut dengan realitas sosial budaya masyarakat pemiliknya. Asumsi ini didasarkan pada kenyataan bahwa ungkapan tersebut sangatlah berkaitan erat dengan realitas sosial masyarakat 
Lubuklinggau yang melatarbelakangi kelahirannya, sekaligus tentu penggunaan ungkapan tersebut di tengah masyarakat Lubuklinggau.

Wallek dan Warren membuat klasifikasi singkat tentang sosiologi sastra (Rene Wallek dan Austin Warren, 1989:85).

1. Sosiologi pengarang, menjelaskan status, ideologi sosial dan lain-lain yang menyangkut pengarang sebagai penghasil karya. Disini akan terlihat suatu penekanan, bagaimana seorang itu hidup di tengah-tengah masyarakat dengan berbagai landasan dan tumpuan sehingga kemudian mampu melahirkan suatu bentuk karya sebagai hasil pemikirannya.

2. Sosiologi karya, memasalahkan karya itu sendiri. Pokok dalam sosiologi karya adalah apa-apa yang tersirat dalam sebuah karya sastra dan apa yang menjadi tujuannya. Pada ruang lingkup ini akan terlihat dengan jelas bagaimana proses yang terjadi secara berturut dan berlahan sehingga sebuah karya itu lahir.

3. Sosiologi pembaca, mempermasalahkan keberadaan seorang pembaca dan pengaruh sosial karya sastra terhadap kehidupannya. Disini akan terlihat nyata penekanan-penekanan fungsi dan peran hadirnya masyarakat pembaca terhadap hadirnya sebuah karya. Pembaca adalah penikmat, hakim dan latar tempat dimana karya itu lahir.

Berdasarkan tiga klasifikasi di atas, analisis terhadap ungkapan tradisional masyarakat Lubuklinggau dilakukan dengan pendekatan sosiologi karya. Klasifikasi ini dimaksudkan untuk menempatkan teks ungkapan tradisional sebagai refleksi sosial budaya masyarakat Lubuklinggau, beserta tujuan dan pesan-pesan moral nilai budaya yang tersirat di dalamnya. Oleh karena itu, di samping menganalisis latar sosial budaya masyarakat yang terefleksi dalam setiap ungkapan tersebut, terlebih dahulu perlu dilihat keutuhan pesan moral yang terdapat pada setiap ungkapan yang berhasil didokumentasi. Sebelumnya, proses pengumpulan serta pengolahan data dan informasi penelitian dilakukan dalam beberapa teknik, yaitu observasi, wawancara, rekam, studi kepustakaan, dan analisis data. Setelah itu, data primer berupa teks 
ungkapan tradisional, terutama untuk menghasilkan pemahaman yang lebih bersifat komprehensif juga dianalisis dengan menggunakan pendekatan hermeneutik.

Secara etimologis hermeneutik berasal dari kata hermeneuein, bahasa yunani, yang berarti menafsirkan atau menginterpretasikan (Ratna, 2004: 45). Pendekatan ini dalam wilayah mitologis dikaitkan dengan Hermes, nama Dewa Yunani yang menyampaikan pesan ilahi kepada manusia. Media pesan ilahi berupa bahasa, baik bahasa lisan maupun bahasa tulisan kemudian ditafsirkan serta disampaikan lewat bahasa, namun bukan bahasa itu sendiri. Teks ungkapan tradisional Lubuklinggau ditempatkan sebagai teks sastra yang perlu ditafsirkan, sebab di satu pihak ia terdiri atas bahasa, di pihak lain, melalui teks ungkapan tersebut tersimpan makna yang tersembunyi, atau dengan sengaja disembunyikan. Hermeneutik berkaitan dengan upaya pemaknaan suatu analog teks ungkapan tradisional; misalnya memahami struktur sosial masyarakat Lubuklinggau melalui pemaknaan cara lisan atau data tekstual ungkapan tradisional. Pertanyaan mendasar adalah : apa arti dan makna teks itu ? Ini berarti, interpretasi adalah upaya untuk membuat jelas atau membuat studi terhadap ungkapan tradisional menjadi bermakna. Sejalan dengan itu (Moleong, 1989: 2) menjelaskan bahwa objek penelitian dalam hermeneutik mesti dalam bentuk teks atau analog teks yang sepintas terlihat kabur serta terkadang saling bertentangan. Interpretasi dimaksudkan agar yang tidak jelas menjadi jelas untuk bisa dipahami. Interpretasi mesti menjadi kerangka berfikir dalam usaha memperjelas pengertian tersembunyi menjadi sesuatu yang bermakna dan jelas.

Hermeneutik menempatkan teks sastra dan filsafat sebagai objek kajian yang seyogiyanya disejajarkan dengan pendekatan interpretasi, pemahaman, versthen dan retroaktif. Dalam ilmu-ilmu sosial juga disebut metode kualitatif, analisis isi, alamiah, naturalistik, studi kasus, etnografi, etnometodologi dan fenomenologi serta biasanya dipertentangkan dengan metode kuantitatif (Moleong, 1989). Akhirnya, pendekatan hermeneutik dinilai tepat untuk digunakan dalam memperkuat analisis teks ungkapan tradisional yang dimiliki secara kolektif oleh masyarakat Lubuklinggau. Tentunya, penggunaan hermeneutik tidak dimaksudkan untuk menghasilkan interpretasi yang 
bersifat paling benar. Setiap peneliti berpeluang bergerak dari langkah awal yang berbeda, sekaligus memperlakukan suatu objek melalui horison dan paradigma yang berbeda.

\section{PEMBAHASAN}

\section{Ungkapan Payu Ponga Nilek Ngelup. Jengan Melawan Wang Tue Nilek}

\section{Meresa}

"Payu ponga nilek ngelup. Jengan melawan wang tue nilek meresak" "Hai kamu nanti celaka. Jangan melawan orang tua nanti tidak berkah" "Hai kamu nanti celaka. Jangan melawan pada orang tua nanti hidup tidak berkah"

Sebagaimana dijelaskan Rosmana Dewi (wawancara tanggal 18 Sepetember 2018), ungkapan payu ponga nilek ngelup. Jengan melawan wang tue nilek meresak (hai kamu nanti celaka, jangan melawan orang tua nanti hidup tidak berkah), diperuntukkan kepada setiap anak remaja di Lubuklinggau. Ungkapan tersebut sangat lazim disampaikan tidak hanya oleh para orang tua, namun juga oleh warga masyarakat kepada para bujang gadis (muda mudi) di Lubuklinggau. Pesan moral sederhana yang ingin disampaikan melalui ungkapan tersebut, setiap bujang gadis (muda mudi) Lubuklinggau mesti berbakti kepada kedua orang tua mereka. Setiap bujang gadis (muda mudi) Lubuklinngau mesti mampu menjadikan kedua orang tua mereka sebagai keramat hidup, sehingga kehidupan mereka senantiasa dilimpahi oleh keberkahan oleh Tuhan Yang Maha Kuasa.

Ungkapan payu ponga nilek ngelup (hai kamu nanti celaka) biasanya disampaikan dengan nada bicara tinggi. Artinya, pengguna ungkapan berada dalam suasana kebatinan yang diselimuti oleh kekhawatiran menyaksikan sikap dan perilaku seorang bujang (pemuda) atau seorang gadis (pemudi). Menurut pengguna ungkapan seorang bujang (pemuda) atau seorang gadis (pemudi) telah berbuat di luar batas kesopanan sebagaimana dipahami oleh masyarakat, sehingga teguran mesti diberikan. Perbuatan bujang gadis (muda mudi) yang dianggap telah melewati batas kesopanan tersebut biasanya terkait dengan pergaulan muda mudi mereka. Tentunya, teguran 
yang berisi kecaman dan rasa kekhawatiran tersebut didasari oleh proses pengamatan berulang yang dilakukan terhadap kecenderungan perilaku yang diperlihatkan oleh bujang gadis (muda mudi). Harapan yang tertompang melalui ungkapan yang bersifat menegur dan mengecam tersebut, baik bujang (pemuda) ataupun gadis (pemudi) memperbaiki sikap dan perbuatannya.

Selanjutnya, ungkapan jengan melawan wang tue nilek meresak (jangan melawan orang tua nanti hidup tidak berkah), biasa disampaikan dengan nada datar. Pengguna ungkapan tidak dalam situasi kebatinan yang diselimuti kekhawatiran, sehingga ungkapan ini lebih bermakna sebagai nasehat dalam kondisi yang relatif normal. Sebagai nasehat, ungkapan ini adakalanya disampaikan langsung oleh orang tua kepada anaknya serta tidak tertutup pula kemungkinan untuk disampaikan oleh orang lain. Kejadian atau peristiwa yang biasanya melatarbelakangi penggunaan ungkapan tersebut biasanya terkait dengan upaya perlawanan atau penentangan dari seorang anak terhadap orang tuanya. Bentuk-bentuk sikap dan perilaku yang menunjukkan bahwa seorang anak telah melakukan perlawanan atau menentang kepada orang tuanya memicu untuk munculnya ungkapan tersebut.

Sebagai bagian dari kearifan lokal masyarakat Lubuklinggau, penggunaan ungkapan jengan melawan wang tue nilek meresak (jangan melawan orang tua nanti hidup tidak berkah) dinilai tepat dan relevan untuk dipertahankan. Menurut Rosmana Dewi, perkembangan ilmu pengetahuan dan teknologi telah banyak mempengaruhi pemahaman generasi muda dalam kaitannya dengan keharusan mereka untuk berbakti kepada orang tua. Berbagai informasi dan pengetahuan baru yang mereka peroleh karena perkembangan teknologi telah menyebabkan bergesernya tatanan nilai terkait dengan pola hubungan antara orang tua dan anak. Oleh karena itu, tetap digunakannya ungkapan tersebut, serta tetap diwariskannya nilai moral sebagaimana terdapat pada ungkapan, dinilai mampu meminimalisis bentuk-bentuk penentangan serta sikap kedurhakaan yang ditunjukkan oleh setiap anak di Lubuklinggau kepada orang tuanya. 
Proses komunikasi dan interaksi antara anak dan orang tua di Lubuklinggau dewasa ini relatif telah diganggu oleh tatanan nilai budaya baru. Tidak jarang ditemukan di Lubuklinggau seorang anak terjerumus pada perbuatan-perbuatan yang notabene bersifat durhaka pada orang tua. Telah banyak ditemukan para orang tua yang tidak lagi dijadikan sebagai keramat hidup oleh anak, sehingga keberkahan hidup anak terlihat semakin jauh untuk bisa diraih. Telah pula ditemukan kasus yang memperlihatkan kehidupan orang tua yang menderita kerena tidak diperhatikan oleh anak-anak mereka. Menurut Rosmana Dewi, kegagalan yang dialami oleh seorang anak karena durhaka kepada orang tua, atau sebaliknya kesengsaraan yang diarasakan oleh tua karena tidak diperhatikan oleh anak, sejatinya menjadi pelajaran. Tidak hanya bagi setiap anak di Lubuklinggau, setiap orang tua pun harus mengambil pelajaran, bahwa hubungan silaturahim antara orang tua dan anak harus tetap terjaga, melampaui ruang dan waktu serta pertambahan usia yang terus terjadi.

Belajar dari nilai budaya masyarakat Lubuklinggau, seperti terefleksi pada ungkapan payu ponga nilek ngelup. Jengan melawan wang tue nilek meresak, mengajak pada menguatnya kesadaran untuk berkaca pada masa lalu. Sebagaimana diceritakan maestro, pada masa lampau kehadiran orang tua dalam kehidupan setiap anak demikian penting dan berharga. Restu dan do'a orang tua bagi kesuksesan setiap anak sangat dibutuhkan. Kesadaran setiap anak untuk tetap berbakti kepada orang tua juga relatif terjaga di masa lampau. Berbeda dengan zaman sekarang, tidak sedikit ditemukan kasus yang menunjukkan bahwa seorang anak telah berbuat durhaka kepada orang tuanya. Tidak sedikit pula cerita yang didengar terkait dengan akibat buruk yang pada akhirnya menimpa diri seorang anak diebabkan oleh kedurhakaannya terhadap orang tua.

Oleh karena itu, melalui ungkapan payu ponga nilek ngelup. Jengan melawan wang tue nilek meresak, masyarakat Lubuklinggau diajak untuk berpikir ulang. Terutama generasi muda Lubuklinggau, melalui ungkapan tersebut berupaya disadarkan kembali pada arti pentingnya orang tua dalam menggapai kesuksesan serta keberkahan hidup yang dicita-citakan. Cerita tentang kesuksesan seorang anak 
merupakan bukti dari buah manis yang berhasil dipetik karena bakti yang diberikan kepada orang tua. Sebaliknya, berbagai kasus yang memperlihatkan betapa sengsaranya kehidupan seorang anak, sekaligus menjadi tanda dari kegagalan yang didapat disebabkan oleh kedurhakaan terhadap orang tua. Pada konteks itu, berbakti kepada orang tua menjadi satu-satunya pilihan, serta durhaka kepada orang tua menjadi larangan yang selamanya mesti dipantangkan.

\section{Ungkapan Awak Tue Betunak Doak Hiyang Melam Kire Nak Ngelong}

"Awak tue betunak daak hiyang melam kire nak ngelong"

"Kamu tua beristri tidak siang malam kira nak melamun"

"Kamu sudah tua beristri tidak siang dan malam pikiran tidak menentu"

Ungkapan awak tue betunak daak hiyang melam kire nak ngelong (kamu sudah tua beristri tidak, siang dan malam pikiran tidak menentu) secara utuh terdapat dalam teks pantun berikut,

Masang sarue umpan dedak, Depat keli ngaleong-leong, Awak tue betunak daak, hiyang melam kire nak ngelong.

(Masang seruas umpan dedak, Dapat keli meliuk-liuk, Badan tua beristri tidak, Siang malam pikiran tak menentu).

Menurut Husni Thamrin, anggota Lembaga adat Kota Lubuklinggau (wawancara tanggal 26 September 2018) teks pantun ini digunakan oleh masyarakat Lubuklinggau tradisional sebagai bentuk kritik, yaitu ketika mengingatkan seorang laki-laki dewasa berusia di atas 40 tahun agar segera berumah tangga. Masyarakat Lubuklinggau memahami bahwa persoalan keterlambatan untuk berumah tangga yang dialami oleh warganya tidak sebatas persoalan pribadi, namun juga persoalan bersama yang mesti dipikirkan secara bersama pula. Oleh karena itu, sebagai bentuk respon positif terhadap kehidupan membujang seorang warga yang dianggap terlalu lama, warga Lubuklinggau mengekpresikannya dalam sebait pantun. Harapannya 
adalah, seorang laki-laki (bujang tua) yang belum juga beristeri semakin menguatkan komitmennya untuk segera menentukan calon istri yang akan mendampinginya mengarungi kehidupan berumah tangga. Di samping itu, penggunaan pantun tersebut dalam satu tindak tutur juga dimaksudkan agar pendengar dari kalangan generasi muda mempersiapkan diri secara lebih dini sebelum memasuki kehidupan berumah tangga.

Di tengah masyarakat tradisional Lubuklinggau teks pantun tersebut juga diungkapan dalam situasi pembicaraan tidak resmi, misalnya dalam pembicaraan lepas di kedai-kedai. Artinya, tidak ada aturan yang bersifat mengikat serta disepakati terkait dengan siapa yang boleh atau tidak boleh menggunakan teks pantun tersebut, termasuk dalam situasi bagaimana pantun tersebut dimunculkan. Sebagaimana disampaikan Rabbani, salah seorang tokoh masyarakat Desa Batu Urip Kecamatan Lubuklinggau Utara II Kota Lubuklinggau (wawancara tanggal 27 September 2018), siapa pun boleh menuturkan teks pantun tersebut. Demikian pula terkait momen pembicaraan yang mendasari munculnya pantun tersebut, tergantung pada relefansi situasi sebagaimana dipahami oleh penuturnya.

Sejauh situasi pembicaraan bersifat relevan dan mendukung, maka salah seorang peserta tindak tutur memiliki keleluasaan dalam menggunakan ungkapan awak tue betunak daak hiyang melam kire nak ngelong. Bahkan, tidak jarang justru kebekuan pembicaraan teratasi ketika salah seorang peserta pembicaraan mengungkapkan pantun tersebut. Sehingga, penggunaan pantun tersebut tidak hanya mengemban misi pengajaran nilai moral budaya masyarakat Lubuklinggau, namun juga terbukti ampuh sebagai pencair kebekuan pembicaraan yang melibatkan beberapa orang warga.

Pesan moral teks pantun dimaksud, secara eksplisit mengemuka pada larik ketiga dan keempat, yaitu bercerita tentang situasi yang kerap dijalani oleh seorang laki-laki (bujang tua) yang tidak beristri. Seorang laki-laki (bujang tua) yang tidak beristeri diceritakan berada dalam situasi berpikir yang serba tidak menentu. Ungkapan "hiyang melam kire nak ngelong" menggambarkan bahwa seorang laki- 
laki (bujang tua) sedang berada dalam situasi psikologi yang bermasalah. Pikiran laki-laki tidak beristri (bujang tua) tersebut dipenuhi oleh berbagai lamunan serta hayalan yang serba tidak menentu. Kondisi tidak nyaman itu berlangsung siang dan malam serta dianggap sebagai potensi personal yang bersifat negatif, baik terhadap dirinya maupun terhadap keluarga dan orang-orang disekitarnya. Oleh karena itu, melalui teks pantun tersebut masyarakat Lubuklinggau tradisional berupaya mengingatkan setiap laki-laki yang telah dewasa untuk segera berumah tangga.

Berdasarkan cerita Syahril Efendi (Wawancara tanggal 27 September 2018), pesan moral masyarakat Lubuklinggau sebagaimana terdapat pada awak tue betunak daak hiyang melam kire nak ngelong tidak hanya bersinggungan dengan kehidupan laki-laki dewasa yang belum berumah tangga. Melalui ungkapan tersebut juga "terberita" tentang laki-laki berusia lanjut yang pernah mengalami kegagalan dalam membina keutuhan berumah tangga. Kegagalan berumah tangga, baik karena alasan bercerai hidup maupun bercerai mati, demikian membebani pikiran si bujang tua, sehingga dia memutuskan untuk hidup sendiri di hari tua.

Pilihan hidup sendiri tampa didampingi oleh seorang isteri ternyata bukan keputusan yang tepat. Si bujang tua menjalani masa-masa sulit kehidupannya seorang diri, tidak ada isteri untuk berbagi keluh dan kesah, sehingga siang dan malam kehidupannya diselimuti oleh ketidakmenentuan pikiran dan perasaan. Situasi kebatinan yang pada mulanya sebatas dialami oleh seorang indifidu tersebut pada gilirannya mendatangkan pengaruh negatif terhadap masyarakat. Kenyataan tersebut disebabkan oleh karena pada tataran yang lebih luas setiap indifidu merupakan bagian tidak terpisahkan dari kehidupan masyarakat itu sendiri

Tepat kiranya, ungkapan awak tue betunak daak hiyang melam kire nak ngelong menjadi wahana lisan masyarakat tradisional Lubuklinggau untuk merefleksikan kegundahan pemahaman kolektif terhadap situasi dan kondisi psikologi "si bujang tua", menjalani hidup diusia lanjut serta tampa seorang isteri yang mendampingi. Secara sosial pula, melalui wahana lisan yang dilahirkan dalam teks pantun tersebut terefleksi suatu kebijaksanaan kolektif masyarakat Lubuklinggau 
dalam merespon situasi dan kondisi yang dialami oleh setiap warga, termasuk dalam hal kehidupan berumah tangga. Kebijaksanaan kolektif tersebut merupakan modal sosial yang harus dipertahankan, sekaligus diperkuat dalam kehidupan di masa sekarang. Berbagai tantangan dan hambatan yang dihadapi oleh masyarakat Lubuklinggau di masa sekarang, disebabkan oleh perkembangan teknologi informasi misalnya, sejatinya tidak berakibat pada tergantikannya modal sosial itu. Kepedulian sosial, terutama dalam konteks kehidupan "bujang tua", mesti tetap menjadi pengikat bagi terwujudnya kebersamaan dalam masyarakat Lubuklinggau.

Masyarakat Lubuklinggau memiliki kepedulian terhadap situasi kebatinan yang dialami oleh seorang laki-laki dewasa, atau mungkin telah lanjut usia, namun tidak memiliki pendamping hidup. Masyarakat di daerah ini sekaligus memiliki pemahaman bahwa fenomena sosial kemanusian sebagaimana dijalanai oleh "bujang tua" bukanlah sekedar persoalan indifidu. Masyarakat mengerti bahwa bila tidak diantisipasi secara bijak, maka fenomena "bujang tua" akan menjadi persoalan sosial yang ikut dirasakan oleh banyak orang. Oleh karena itu, menurut maestro, meskipun teks pantun tersebut dikemukakan pada sebuah pertemuan informal yang melibatkan beberapa orang warga Desa Batu Urip Taba Kecamatan Lubuklinggau Utara II, misalnya pada sebuah kedai, namun sejatinya telah merefleksikan kearifan lokal masyarakat Lubuklinggau secara keseluruhan.

\section{Ungkapan Lah Ngidar Lah Baputar Lom Dopat Jelan Hatuju}

"Lah ngidar lah baputar lom dəpat jelan hatuju"

"Sudah keliling sudah berputar belum dapat jalan sejutu"

"Sudah dibicarakan secara berulang-ulang namun belum didapat persetujuan"

Secara lengkap ungkapan lah ngidar lah baputar, lom dəpat jelan hatuju terdapat dalam teks pantun berikut,

Nabuh seruling berbunyi gitar, Gitar ditabuh talinya tujuh,

Lah ngidar lah baputar, Lom dapat jelan hatuju. 
(Nabuh seruling berbunyi gitar, Gitar ditabuh talinya tujuh,

Sudah keliling sudah berputar, Belum didapat jalan setuju).

Berdasarkan keterangan Basyir, tokoh masyarakat Desa Batu Urip Kecamatan Lubuklinggau Utara II Kota Lubuklinggau (wawancara tanggal 25 September 2018), pada mulanya teks pantun ini diungkapkan oleh seorang juru runding yang mewakili keluarga besar calon pengantin pria atau wanita, yaitu dalam prosesi pertunangan. Artinya, pada konteks awalnya penggunaan teks pantun tersebut muncul dalam pembicaraan yang resmi bernuansa adat Lubuklinggau. Namun demikian, dalam perkembangannya teks pantun dimaksud juga kerap digunakan dalam pembicaraanpembicaraan yang terjadi di tengah masyarakat. Meskipun tidak terkait dengan tema pembicaraan yang membahas persoalan perkawinan serta tidak bersifat resmi bernuansa adat, namun teks pantun ini juga sering digunakan. Pada situasai pembicaraan tidak resmi tersebut penggunaan pantun biasanya dimaksudkan untuk tujuan menegaskan bahwa kesepakatan di antara mereka yang terlibat pembicaraan tidak kunjung didapat.

Isyarat penting berkaitan dengan situasi pembicaraan yang berupaya digambarkan oleh pengguna ungkapan adalah adanya kebuntuan dalam mengambil keputusan, baik dalam pembicaraan resmi bernuansa adat maupun dalam pembicaraan-pembicaraan tidak resmi. Dua lirik terakhir teks pantun bercerita tentang alotnya pembahasan tentang suatu topik pembicaraan yang melibatkan beberapa orang, sekaligus kebuntuan persepsi terkait hal-hal yang bisa mereka sepakati. Pengungkapan teks lah ngidar lah baputar menggambarkan proses pembahasan yang berjalan alot serta telah memakan waktu yang relatif lama. Berbagai usulan, argumentasi serta pertimbangan telah dikemukakan oleh satu pihak kepada pihak lain yang terlibat dalam pembicaraan tersebut, namun tetap saja kesepakatan tidak didapatkan. Selanjutnya, pada lirik keempat, lom dapat jelan hatuju, terbaca bahwa seluruh energi yang dikeluarkan dalam satu pembicaraan 
ternyata tidak berujung pada didapatnya kesamaan persepsi dan pemahaman. Setiap pihak yang terlibat dalam pembicaraan tidak menemukan jalan keluar dari persolan yang sedang dibahas, sehingga kesepakatan tidak terwujud.

Pada prosesi pertunangan bujang gadis (muda mudi), salah satu tahapan dalam tradisi perkawinan masyarakat Lubuklinggau, pembicaraan resmi antara kedua belah pihak diwakili oleh dua orang juru runding. Menurut maestro, pada pembicaraan tersebut seluruh topik yang dibahas, baik terkait dengan persoalan adat, kepentingan keluarga pihak laki-laki dan perempuan, maupun terkait dengan kepentingan masyarakat sekitar, diutarakan oleh dua orang juru runding itu. Adakalanya pembicaraan antara dua juru runding berjalan sederhana dan singkat, dalam pengertian kesepakatan serta keputusan bersama secepatnya bisa didapat. Namun sebaliknya, tidak jarang terjadi justru pembicaraan berjalan alot. Kedua juru runding terlibat dalam pembicaraan yang melelahkan, perdebatan mewarnai pembicaraan, serta kesepakatan yang tidak kunjung diperoleh. Kedua juru runding tidak kunjung menemukan titik temu dalam pembahasan satu topik, misalnya terkait dengan bentuk kebiasaan yang akan diterapkan dalam prosesi perkawinan.

Menurut Syahril Efendi, tokoh masyarakat Desa Batu Urip Kecamatan Lubuklinggau Utara II Kota Lubuklinggau (Wawancara tanggal 27 September 2018), pesan moral yang terefleksi melalui teks pantun ini berkaitan dengan perlunya kesiapan mental dan pengetahuan masyarakat dalam melalui setiap tahapan perkawinan sebagaimana dipahami oleh masyarakat adat Lubuklinggau. Setiap keluarga akan melewati tahapan pertunangan dalam tradisi perkawinan, sehingga mesti mempersiapkan diri secara matang. Setiap keluarga akan bertindak sebagai pihak yang meminang atau sebaliknya bertindak sebagai pihak yang dipinang. Oleh karena itu, segala kemungkinan yang kerap ditemukan dalam pembicaraan yang melibatkan kedua belah pihak mesti diantisipasi secara baik.

Setiap keluarga di Lubuklinggau mesti menyiapkan seorang juru runding yang lihai, sehingga pembicaraan dalam prosesi pertunangan tidak mengalami kebuntuan. Kontribusi pemikiran, pengetahuan, dan kelihaian berkomunikasi dari seorang juru 
runding sebagaimana dipahami oleh masyarakat Lubuklinggau, sangat menentukan terakomodir atau tidaknya kepentingan keluarga yang diwakili. Seorang juru runding merupakan ujung tombak bagi kesuksesan perundingan yang akan berlangsung, prosesi pertunangan berjalan lancar dan tahapan dalam adat perkawinan bila dilanjutkan.

\section{Ungkapan Makan Ati Nenggung Sedingan Rube Abis Resan Urung}

"Makan ati nenggung sedingan rube abis resan urung"

"Makan hati menanggung sedih hantaran habis sepakat belum"

"Kesedihan mendalam, hantaran habis kesepakatan tidak diperoleh"

Ungkapan makan ati nenggung sedingan, rube abis resan urung diambil dari teks pantun berikut,

Tinggi tebing belakang mayan, Tebing terebis polau kan nyorong, Makan ati nenggung sedingan,

Rube abis resan urung.

(Tinggi tebing belakang bambu, Tebing runtuh pulau kan timbul, Makan hati menanggung sedih, Hantaran habis sepakat belum).

Berdasarkan cerita Suwandi Syam, pemerhati sejarah dan budaya Lubuklinggau, (wawancara tanggal 26 September 2018) melalui teks pantun ini terekpresi kekecewaan yang dialami oleh keluarga pihak laki-laki (bujang) karena batalnya perjodohan anak mereka dengan seorang perempuan (gadis). Kekecewaan keluarga pihak laki-laki (bujang) tersebut digambarkan semakin bertambah karena dalam pelaksanaan prosesi pertunangan mereka telah mengeluarkan biaya yang tidak sedikit, terutama untuk mempersiapkan kelengkapan hantaran yang mesti diserahkan kepada keluarga pihak perempuan (gadis). Ekspresi kekecewaan tersebut sesungguhnya juga terkait dengan persoalan harga diri keluarga pihak laki-laki, sekaligus kehormatan dari calon mempelai mereka (bujang). Bagaimanapun, batalnya 
rencana perjodohan tersebut, terlepas dari persoalan biaya kelengkapan hantaran yang telah dikeluarkan, terkait erat dengan persoalan harga diri dan kehormatan keluarga. Oleh karena itu, persoalan tidak serta merta selesai setelah perjodohan dinyatakan batal, namun berdampak pada kesiapan mental bagi keluarga pihak laki-laki dalam menentukan sikap terkait dengan masa depan anak bujang mereka.

Melalui ungkapan makan ati nenggung sedingan (makan hati menanggung sedih) tergambar bagaimana luka dan kekecewaan yang dirasakan oleh keluarga pihak laki-laki (bujang). Luka batin tersebut demikian dalam sehingga dipahami sebagai persoalan yang semakin hari akan terasa semakin membebani. Selanjutnya, pada ungkapan rube abis resan urung (hantaran habis sepakat belum) terinformasikan persoalan sesungguhnya yang sedang dihadapi, yaitu telah habisnya hantaran pertunangan yang mereka bawa, namun perjodohan ternyata mengalami pembatalan.

Tidak disebutkan dalam teks pantun, baik secara eksplisit maupun secara implisit, penyebab batalnya perjodohan. Artinya, secara bijak melalui beberapa ungkapan pendek yang hanya diinformasikan suasana kebatinan keluarga pihak lakilaki (bujang) yang sedang didera oleh rasa sedih dan kecewa mendalam.

Sebagaimana dijelaskan Suwandi Syam, suksesi pertunangan merupakan satu tahapan penting yang mesti dilewati oleh setiap keluarga dalam prosesi perkawinan masyarakat Lubuklinggau. Berhasilnya pertunangan antara seorang laki-laki dengan seorang perempuan (bujang dan gadis) tidak hanya menentukan kelanjutan kehidupan bagi seorang calon mempelai. Berhasilnya pertunangan tersebut juga terkait dengan martabat serta kehormatan keluarga pihak laki-laki di tengah masyarakat. Apabila pertunangan berjalan lancar serta kepastian jodoh bagi seorang laki-laki (bujang) diperoleh, maka secara sosial keberadaannya akan semakin mendapat tempat di masyarakat. Laki-laki (bujang) tersebut akan semakin menemukan ruang untuk terlibat aktif dalam berbagai kegiatan sosial kemasyarakatan. Keluarga pihak laki-laki (bujang) pun akan dipandang oleh masyarakat. Keluarga tersebut dianggap berhasil menjaga dan memelihara kehormatan, terutama karena pinangannya diterima oleh keluaga pihak perempuan (gadis). 
Berbeda kenyataan bila pertunangan tersebut menemui kegagalan dan perjodohan antara seorang laki-laki (bujang) dengan seorang perempuan (gadis) dinyatakan batal. Setiap laki-laki (bujang) yang mengalami kegagalan perjodohan akan mengalami beban moral dalam pergaulannya di tengah masyarakat. Ruang partisipasi sosial laki-laki (bujang) tersebut akan terasa sempit disebabkan oleh deraan beban psikologi kegagalan yang dialami. Keluarganya pun ikut menanggung malu disebabkan oleh kegagalan perjodohan. Secara sosial kemasyarakatan eksistensi keluarga tersebut dipertanyakan, terutama disebabkan oleh telah gagalnya mereka menjodohkan seorang anak laki-laki (bujang). Kerugian yang dialami pada gilirannya tidak sebatas habisnya kelengkapan hantaran pertunangan, namun lebih pada persoalan harga diri dan martabat keluarga. Oleh karena itu, melalui pantun dimaksud segala bentuk kesedihan dan kekecewaan berupaya diekspresikan.

Pesan moral masyarakat Lubuklinggau sebagaimana direfleksikan oleh pantun, secara khusus oleh ungkapan makan ati nenggung sedingan rube abis resan urung, berkaitan dengan pentingnya komitmen keluarga dalam usaha memelihara harga diri serta martabat. Setiap keluarga menginginkan dipandang terhormat oleh keluarga lain dan masyarakat. Melalui ungkapan ini sekaligus diajarkan pentingnya kompromi dalam berbagai aspek kehidupan bermasyarakat, sehingga tidak ditemukan adanya pihak-pihak yang merasa dikecewakan. Kesadaran bahwa luka seorang individu anggota masyarakat merupakan luka bagi setiap anggota masyarakat perlu dibina, sehingga jalinan silaturahmi antara sesama warga terus terbina. Lebih dari itu, kepedulian satu anggota keluarga dalam ikut menjaga martabat serta kehormatan anggota keluarga yang lain, seyogianya semakin menguat, sehingga eksistensi masyarakat dapat dipertahankan. Pesan moral ini, bagian dari kearifan lokal masyarakat Lubuklinggau, terpatri dalam satu bait teks pantun yang sejatinya tetap diwariskan kepada generasi muda di masa sekarang.

\section{Ungkapan Lambat Bekat Gocang Dopat}

\section{"Lambat bekat gacang dəpat"}


"Lambat berkah kencang dapat"

"Lambat membawa berkah kencang segera mendapat"

Dijelaskan oleh Lusiana, staf Dinas Pendidikan dan Kebudayaan Kota Lubuklinggau sekaligus pemerhati sosial budaya Lubuklinggau (wawancara tanggal 27 September 2018) nilai moral yang terdapat dalam ungkapan lambat bekat gəcang dapat (lambat berkah kencang dapat) telah lama menjadi bagian dari kearifan lokal masyarakat Lubuklinggau. Melalui ungkapan ini masyarakat Lubuklinggau sejak zaman dahulu terus berupaya menanamkan pentingnya ketelitian serta kecepatan dalam melakukan pekerjaan. Pada zaman dahulu di tengah warga Desa Batu Urip misalnya, para orang tua, tokoh masyarakat dari kalangan ulama, pemangku adat serta kalangan cerdik pandai, senantiasa mengajarkan perlunya ketelitian serta kecepatan dalam bekerja dan berusaha. Berbagai kesempatan yang tersedia, baik dalam forum-forum pertemuan resmi seperti pada rapat yang berlangsung di Balai Desa Batu Urip, maupun dalam diskusi-diskusi yang berlangsung secara informal seperti dalam diskusi keluarga, semangat kehati-hatian serta kecepatan senantiasa menjadi wejangan yang disampaikan. Meskipun demikian, dalam perkembangan kehidupan warga desa dewasa ini penggunaan ungkapan semakin jarang terdengar.

Secara sederhana melalui ungkapan lambat bekat gacang dapat (lambat berkah kencang dapat) masyarakat Lubuklinggau dihadapkan pada dua pilihan yang sama-sama baik. Pilihan pertama, lambat bekat (lambat berkah), berarti bekerja dan berusaha dengan penuh ketelitian serta kehati-hatian, meskipun terkadang memunculkan kesan lambat. Pada pilihan kedua, gəcang dəpat (kencang dapat), yaitu bekerja dan berusaha secara tanggap dan cepat. Masyarakat memiliki keleluasaan untuk memilih salah satu dari kedua pilihan tersebut, sekaligus juga dimungkinkan untuk memilih keduanya secara bersamaan.

Mengambil kedua pilihan secara bersamaan. Berdasar cerita Suwandi Syam (Wawancara tanggal 29 september 2018), dengan pilihan tersebut berarti masyarakat Lubuklinggau disarankan untuk senantiasa mengedepankan kehati-hatian dan 
ketelitian sekaligus berupaya tetap berkomitmen pada prinsip kerja cepat dan tuntas. Prinsip kehati-hatian diyakini akan mengundang turunnya berkah dalam setiap usaha dan pekerjaan yang dilakoni. Selanjutnya, berkomitmen pada kecepatan kerja dipercaya akan mengantarkan setiap warga pada hasil yang diharapkan secara cepat.

Pada ungkapan lambat bekat (lambat berkah) terselip pesan agar selalu teliti dan berhati-hati dalam bekerja dan berusaha. Artinya, terdapatnya kata "lambat" pada ungkapan lambat bekat (lambat berkah) tidak dimaksudkan bahwa dalam bekerja dan berusaha terbuka peluang untuk berlambat-lambat, sehingga pekerjaan tidak tuntas sesuai waktu yang ditargetkan. Demikian pula halnya, pada ungkapan gəcang dəpat (kencang dapat) terdapat pesan agar dalam setiap berusaha setiap orang berkomitmen pada kecepatan kerja. Kata gecang (kencang) dalam ungkapan ini dimaksudkan supaya setiap orang dalam usahanya mementingkan prinsip kecepatan, sehingga setiap pekerjaan tuntas sesuai waktu yang direncanakan. Oleh karena itu, ungkapan lambat bekat gəcang dəpat epat (lambat berkah kencang dapat) sejatinya menjadi spirit dalam bekerja dan berusaha bagi masyarakat Lubuklinggau. Sebagai spirit dalam berusaha dan bekerja kehati-hatian serta kecepatan seyoginya pula terinternasisasi dalam setiap pribadi warga masyarakat di Lubuklinggau.

Pesan moral ungkapan lambat bekat gacang dəpat merupakan bagian dari kearifan lokal masyarakat Lubuklinggau. Pesan moral tersebut merupakan warisan nenek moyang yang mesti terus diwariskan kepada masyarakat, terutama kepada generasi muda. Sebagaimana ditekankan oleh Suwandi Syam, masyarakat Lubuklinggau dewasa ini harus banyak belajar dari pemikiran serta bentuk-bentuk kebijaksanaan sebagaimana dipraktikkan oleh masyarakat Lubuklinggau tempo dulu. Kemajuan ilmu pengetahuan dan teknologi tidak seharusnya menjadi bumerang yang menyebabkan masyarakat Lubuklinggau melupakan warisan kearifan yang ditinggalkan oleh para pendahulu. Masyarakat Lubuklinggau, khususnya generasi muda, sepantasnya membuka diri terhadap perubahan zaman, namun tetap dalam komitmen bersama untuk menjaga dan mempertahankan bentuk-bentuk kearifan bersikap dan berperilaku sepertihalnya diharapkan oleh para leluhur. 


\section{PENUTUP}

Melalui tulisan ini disimpulkan sebagai berikut :

Pertama, ungkapan tradisional yang dijelaskan terkait dengan refleksi nilai budaya masyarakat Lubuklinggau Sumatera Selatan adalah : (1) Ungkapan payu ponga nilek ngelup. Jengan melawan wang tue nilek meresak; (2) Ungkapan awak tue betunak daak hiyang melam kire nak ngelong; (3) Ungkapan lah ngidar lah baputar lom dopat jelan hatuju; (4) Ungkapan makan ati nenggung sedingan rube abis resan urung; (5) Ungkapan lambat bekat gacang dapat. Kedua, nilai budaya yang direfleksikan oleh setiap ungkapan adalah, nilai kepatuhan, nilai kesungguhan, nilai pengetahuan, nilai kompromi, dan nilai kecermatan, terutama terkait dengan beberapa hal, yaitu : (1) Pentingnya komitmen untuk senantisa berbakti dan patuh kepada orang tua; (2) Pentingnya isteri serta kesungguhan untuk menjaga keutuhan keluarga; (3) Perlunya pengetahuan dalam memahami dinamika dialog yang berkembang di tengah masyarakat; (4) Perlunya kompromi dalam menjaga jalinan silaturahim antar warga masyarakat; dan (5) Perlunya kecermatan sekaligus kecepatan dalam setiap bidang usaha yang ditekuni.

Penting dilakukan kajian lanjutan terhadap ungkapan tradisional masyarakat Lubuklinggau Sumatera Selatan, baik dalam kepentingan mendokumentasi teks ungkapan, maupun dalam kerangka menemukenali khasanah nilai budaya yang terdapat pada ungkapan-ungkapan dimaksud. Kajian yang berkelanjutan serta dilakukan dengan pendekatan keilmuan yang relevan dinilai sebagai upaya strategis dalam mengantisipasi agar tidak terkondisinya ungkapan tradisional Lubuklinggau menuju kepunahan. Pelaksanaan kajian tersebut sekaligus sebagai usaha melestarikan khasanah budaya lokal bagi penguatan karakter kepribadian masyarakat khususnya generasi muda. 


\section{DAFTAR PUSTAKA}

Atmazaki. 2005. Ilmu Sastra : Teori dan Terapan. Padang : Citra Budaya Indonesia.

Damono, Sapardi Djoko. 1984. Sosiologi Sastra Sebuah Pengantar Ringan. Pusat Pembinaan dan Pengembangan Bahasa Departemen Pendidikan dan Kebudayaan.

Hutomo, Suripan Sadi. 1991. Mutiara Yang Terlupakan; Pengantar Studi Sastra Lisan. Surabaya: HISKI Komisariat Jawa Timur.

Koenjraningrat. 2002. Kebudayaan, Mentalitas dan Pembangunan. Jakarta : PT Gramedia Pustaka Utama.

Luxemburg, Jan Van dkk. 1984. Pengantar Ilmu Sastra. Jakarta : Gramedia.

Moleong, J. Lexy. 2009. Metodologi Penelitian Kualitatif. Bandung: PT Remaja Rosdakarya.

Ratna, Nyoman Kutha. 2004. Teori, Metode, dan Teknik Penelitian Sastra. Pustaka Belajar.

Sedyawati, Edi. 2006. Budaya Indonesia:Kajian Arkeologi, Seni dan Sejarah. Yokyakarta : Rajawali Pers.

Warren, Rene dan Austin Warren. 1989. Teori Kesusastraan, terj. Melani Budianto. Jakarta. 